\title{
Review
}

(Departamentos de Microbiología ${ }^{1}$ y Estomatología ${ }^{2}$, Universidad de Granada, Granada, Spain ${ }^{3}$ Departamento de Inmunología, Microbiología y Parasitología, Facultad de Medicina y Odontología, Universidad del País Vasco, Bilbao, Spain)

\section{Candida dubliniensis, a new fungal pathogen}

\author{
J. GutIÉRREZ $\left.{ }^{1, *}\right)$, P. MORALES ${ }^{2}$, M. A. GONZÁLEZ² and G. QuINDÓS ${ }^{3}$
}

(Received 27 October 2000/Accepted 20 December 2001)

There is a high interest in Candida species other than Candida albicans because of the rise and the epidemiological shifts in candidiasis. These emerging Candida species are favored by the increase of immunocompromised patients and new medical practices, and most oropharyngeal candidiasis are observed in HIV-infected patients. Candida dubliniensis is a recently described opportunistic pathogen that is closely related to C. albicans but differs from it with respect to epidemiology, certain virulence characteristics, and the ability to develop fluconazole resistance in vitro. C. dubliniensis has been linked to oral candidiasis in AIDS patients, although it has recently been associated to invasive disease. C. dubliniensis shares diagnostic characteristics with $C$. albicans, as germ tube- and chlamydospore-production, and it is generally misclassified as $C$. albicans by standard diagnostic procedures. Several recent studies have attempted to elucidate useful phenotypic and genotypic characteristics for separating both species. A large variety of methods have been developed with the aim of facilitating rapid and accurate identification of this species. These have included differential chromogenic culture media, immunological tests, and enhanced biochemical and enzymatic panels. Chromogenic isolation media, as CHROMagar Candida, demonstrate better detection rates than traditional media, and allow the presumptive identification of $C$. dubliniensis by means of colony color (dark-green colonies). API 20 C AUX system is considered a reference method, but ID $32 \mathrm{C}$ strip, and the VITEK 2 ID-YST system correctly identify most $C$. dubliniensis isolates, being the latter the most accurate. Spectroscopic methods, such as Fourier transformed-infrared spectroscopy, offer potential advantages. However, many authors consider that standard methods for differentiation of Candida species are timeconsuming, often insensitive and can fail to distinguish C. dubliniensis. To overcome these drawbacks, molecular tools have been developed to discriminate C.dubliniensis, and particularly those based on the polymerase chain reaction. But, molecular tools prove difficult and too complex for routine use in the clinical laboratory setting and new developments are necessary. Although preliminary studies indicate that most strains of $C$. dubliniensis are susceptible to antifungal agents, fluconazole-resistant strains have been detected. Furthermore, fluconazole-resistant strains are easily derived in vitro, showing an increased expression of multidrug resistance transporters, as MDR1.

The augmentation of mycoses has been favored by the increased numbers of immunocompromised individuals and species previously not associated with human disease and novel species have been identified as potential pathogens (COLEMAN et al. 1998, PONTÓN et al. 2000, SANDVEN 2000). A clear paradigm of this phenomenon is Candida dubliniensis that was first identified as a new species by Sullivan et al. (1995) in Dublin, Ireland while performing an epidemiological investigation of oral candidiasis in HIV-infected and AIDS patients in the early 1990s. Some germ tube- and chlamydospore-positive isolates, initially identified as 'atypical' Candida albicans, failed to hybridize efficiently with the C. albicans-specific DNA fingerprinting probe 27A. Subsequent analysis of these isolates showed that they constituted a distinct species closely related to C. albicans (Sullivan et al.

*) Corresponding author: Prof. Dr. J. GuTIÉRREZ; e-mail: josegf@ugr.es 
Table 1

Epidemiology of human colonization and infection by Candida dubliniensis

\begin{tabular}{|c|c|}
\hline Clinical specimen/Continent & Reference \\
\hline \multicolumn{2}{|l|}{ Oral } \\
\hline Asia & POLACHECK et al. (2000), TAMURA et al. (2000) \\
\hline Australia and Pacific Islands & MCCULLOUGH et al. (1995) \\
\hline Europe & $\begin{array}{l}\text { SULLIVAN } \text { et al. (1993, 1997), BOERLIN } \text { et al. (1995), PUJOL } \\
\text { et al. (1997), BIKANDI } \text { et al. (1998), CEBALLOS } \text { et al. (1998), } \\
\text { ODDS et al. (1998), DÍAZ-GUERRA et al. (1999), STAIB and } \\
\text { MORSCHHÄUSER (1999), VELEGRAKI et al. (1999), BADOC } \text { et al. } \\
\text { (2000), GIAMMANCO } \text { et al. (2000), KURZA et al. (2000), } \\
\text { TINTELNOT et al. (2000), QUINDÓS et al. (2000), WILLIS } \text { et al. } \\
\text { (2000), MOALIC } \text { et al. (2001) }\end{array}$ \\
\hline North America & $\begin{array}{l}\text { KIRKPATRICK et al. (1998), SALKIN et al. (1998), JABRA-RIZK } \\
\text { et al. (1999), MEILLER et al. (1999), BROWN et al. (2000), RED- } \\
\text { DING et al. (2001), SEBTI et al. (2001) }\end{array}$ \\
\hline South America & RODERO et al. (1998), SANO et al. (2000), ALVES et al. (2001) \\
\hline \multicolumn{2}{|l|}{ Vaginal } \\
\hline Europe & $\begin{array}{l}\text { COLEMAN et al. (1997a), KURZAI et al. (2000), QUINDÓs et al. } \\
\text { (2000) }\end{array}$ \\
\hline \multicolumn{2}{|l|}{ Blood } \\
\hline Australia and Pacific Islands & MARRIOTT et al. (2001) \\
\hline Europe & MEIS et al. (2000), SALESA et al. (2001) \\
\hline North America & Brandt et al. (2000), Sebti et al. (2001) \\
\hline Other & (feces, urine, respiratory specimens and wounds) \\
\hline Asia & Polacheck et al. (2000), Kamei et al. (2000) \\
\hline
\end{tabular}

1999). Afterwards, C. dubliniensis isolates have been identified in a wide range of clinical settings by many different laboratories (Table 1). But probably C. dubliniensis has been present in the community for a long time and has been misidentified as $C$. albicans. This species is primarily associated with recurrent episodes of oral candidiasis in AIDS and HIVinfected patients. However, C. dubliniensis has also been implicated in cases of superficial and disseminated candidiasis in patients with and without HIV infection.

The purpose of this article is to review the most recent information available on $C . d u b$ liniensis and the relevance of this species in human disease. In particular we wish to highlight the advances being made in the development of rapid and accurate tests to allow the discrimination of $C$. dubliniensis from other Candida species, especially C. albicans.

\section{Epidemiology}

C. dubliniensis was originally identified by SULLIVAN et al. (1995) in oral specimens from Irish HIV-infected and AIDS patients with recurrent oral candidiasis. Since then this species has been isolated from a wide variety of clinical settings and there have been many recent reports of the identification of this species throughout the world (Table 1). However, the earliest known isolates of $C$. dubliniensis precede the AIDS pandemics and there have been one isolate deposited in the Centraal Bureau voor Schimmelcultures in Holland as C. albi- 
cans in 1952 (ODDS et al. 1998) and another in the British National Collection for Pathogenic Fungi as Candida stellatoidea in 1957 (SULLIVAN et al. 1995). This emphasizes the problem of misidentification of $C$. dubliniensis isolates due to its phenotypic similarity with C. albicans as in two separate retrospective studies on yeast stock collections, approximately $2 \%$ of germ tube and chlamydospore-positive isolates originally identified as $C$. albicans have been found to be $C$. dubliniensis (Coleman et al. 1997b, Odds et al. 1998). A similar investigation of a collection of oral yeast isolates from HIV-infected individuals originally identified as C. albicans revealed that $16.5 \%$ were C. dubliniensis (Coleman et al. 1997a).

C. dubliniensis has been mainly recovered from the oral cavity of HIV-infected patients with oral candidiasis as mixed cultures with other species of Candida, but some studies have shown that between 5 and $10 \%$ of HIV-infected patients with oral candidiasis yielded C. dubliniensis in pure culture (COLEMAN et al. 1993, 1997a, 1997b, CEBALlos et al. 1998). MEILLER et al. (1999) found that a history of intravenous drug abuse was present in $50 \%$ of the $C$. dubliniensis -positive patients, and in their study, C. dubliniensis represented $25 \%$ of the yeast-positive cultures. The most common clinical manifestations of oral $C$. dubliniensis infection are the erythematous and pseudomembranous forms (COLEMAN et al. $1997 \mathrm{a}$, CEBALlos et al. 1998). Recently, C. dubliniensis has also been implicated in an unusual form of linear gingival erythematous candidiasis (VELEGRAKI et al. 1999).

This species can cause oral disease in non-HIV-infected persons and be an oral colonizer at low incidence levels in normal healthy individuals. REDDING et al. (2001) described a mixed infection of $C$. dubliniensis and $C$. albicans in a patient undergoing head and neck radiation for oral cancer who developed oropharyngeal candidiasis. WILLIS et al. (2001) reported that $70 \%$ of 414 insulin-using diabetes mellitus patients carried Candida species in the oral cavity. In this study, C. albicans was the most commonly isolated, followed by C. dubliniensis, which was isolated on 64 occasions. Colonization with multiple Candida species was common, and $C$. dubliniensis was present in both carriage and disease states. Seven patients without signs of oral disease had $C$. dubliniensis isolated as the sole Candida species, while the same species was associated with various forms of oral candidiasis in six patients.

Moreover, isolates of $C$. dubliniensis have been recovered from cases of systemic disease in HIV- and non-HIV-infected patients (PINJON et al. 1998, MEIS et al. 1999, SALESA et al. 2000, MARRIOTT et al. 2001, SEBTI et al. 2001) and from vaginal, urinary and fecal specimens (SULLIVAN et al. 1995, ODDS et al. 1998, QUINDÓs et al. 2000). MEIS et al. (1999) reported three cases of candidemia ( $C$. dubliniensis-positive blood cultures) due to this species in HIV-negative patients with chemotherapy-induced immunosuppression and bone marrow transplantation, one patient receiving cytotoxic chemotherapy for relapsed rhabdomyosarcoma and two patients following allogeneic hematopoietic stem cell transplants. POLACHECK et al. (2000) described the isolation of five C. dubliniensis strains, one of the five isolates was recovered from urine, and while the remaining four were recovered from upper respiratory tract and oral specimens. None of the patients was HIV positive, but all were receiving broad-spectrum antibacterial agents at the time of $C$. dubliniensis isolation. Finally, SALESA et al. (2001) have described a case of a $C$. dubliniensis candidemia in a non-neutropenic patient. Although the portal of entry for candidemia was unknown, the authors believed that it might be related to the intravenous use of cocaine by the patient. Two of the patients reported by BRANDT et al. (2000) had a history of intravenous drug abuse too. Six C. dubliniensis isolates, initially identified as $C$. albicans, have also been isolated from Spanish intravenous drug user (ODDS et al. 1998).

The relative clinical importance of $C$. dubliniensis requires further investigation of its epidemiology and virulence, and these studies should be facilitated by the development of reliable identification techniques. 
Table 2

Useful phenotypical characteristics for identification of Candida dubliniensis

\begin{tabular}{ll}
\hline Test name & Reference \\
\hline Germ tube production in serum & SULLIVAN et al. (1995) \\
Absence of growth at $42-45^{\circ} \mathrm{C}$ & PINJON et al. (1998) \\
Characteristic rough-looking colonies on STAIB agar & STAIB and MORSCHHÄUSER (1999) \\
Characteristic chlamydospores on STAIB agar & STAIB and MORSCHHÄUSER (1999) \\
Initial dark green colonies on CHROMagar Candida & KIRPATRICK et al. (1998) \\
Non-fluorescent colonies on methyl-blue SABOURAUD agar & SCHOOFS et al. (1997) \\
Turquoise smooth colonies on Candida ID agar & QUINDÓS et al. (2001) \\
Reduction of tetrazolium salts & VELAGRAKI and LOGOTHETI (1998) \\
Absence of beta glucosidase activity & BOERLIN et al. (1995) \\
Antigenic differences with $C$. albicans by IFA & BIKANDI et al. (1998), \\
& MAROT-LEBLOND et al. (2000) \\
\hline
\end{tabular}

\section{Phenotypic characteristics}

In the early 1990s, many authors described the recovery of atypical oral Candida isolates from HIV-infected patients. These isolates produced germ tube and chlamydospores (features used for definitive C. albicans identification), and had a similar antigenicity as C. albicans serotype A, but they showed ATB ID32C and API 20C carbohydrate assimilation profiles that not correlated precisely to $C$. albicans or any other yeast species included in these databases. These isolates known now as $C$. dubliniensis are closely related to $C$. albicans (COLEMAN et al. 1997a, SULLIVAN et al. 1995) and differentiation between the two species in the clinical laboratory remains difficult (Table 2).

C. dubliniensis produces chlamydospores more readily and abundantly on Rice agar Tween, Tween 80-oxgall-caffeic acid or cornmeal agar than C. albicans (SULLIVAN et al. 1993, 1997, JABRA-RIZK et al. 1999a, KOEHLER et al. 1999). A high frequency of chlamydospore formation has been observed in approximately 57\% of C. dubliniensis isolates and only in approximately $15 \%$ of C. albicans isolates (SULLIVAN and COLEMAN 1998). However, this has not been shown to be reproducible in some laboratories (SCHOOFS et al. 1997). In a recent study with North American $C$. dubliniensis isolates, $70 \%$ of them produced abundant chlamydospores; however, $3.6 \%$ of $C$. albicans isolates also exhibited a similar phenotype (KIRKPATRICK et al. 1998).

STAIB and coworkers (STAIB and MorSCHHÄUSER 1999, STAIB and ARASTEH 2001) have suggested that the ability of $C$. dubliniensis to produce rough colonies and chlamydospores on STAIB agar (Syn. Guizotia abyssinica creatinine agar) provided a simple means of differentiating it from its close relative $C$. albicans. On these agar plates, $C$. dubliniensis formed rough colonies due to mycelial growth and produced abundant chlamydospores whereas C. albicans grew only in smooth colonies and without chlamydospore formation. In a recent study, AL-MosaID et al. (2001) observed that while none of the C. albicans isolates produced chlamydospores on either STAIB agar or Caffeic acid-ferric citrate agar, more than $84 \%$ of the C. dubliniensis isolates produced chlamydospores on both of them. All of the C. albicans isolates grew as smooth, shiny colonies on STAIB agar after $48-72 \mathrm{~h}$ at $30{ }^{\circ} \mathrm{C}$, while most $C$. dubliniensis isolates grew as rough colonies, many (approximately 65\%) with a hyphal fringes. In contrast, most $C$. albicans and $C$. dubliniensis isolates grew as rough colonies on Caffeic acid-ferric citrate agar. For these authors (AL-MoSAID et al. 2001), discrimination between these two species on STAIB agar was best achieved on the basis of colony morphology rather than chlamydospore production. 
C. dubliniensis isolates (Sullivan et al. 1995, Sullivan and Coleman 1997, 1998) grow well at $30-37^{\circ} \mathrm{C}$, as creamy white colonies on solid media, such as Glucose SABOURAUD agar or Potato dextrose agar, but these colonies are indistinguishable from those of C. albicans. However, unlike C. albicans colonies, C. dubliniensis do not grow or grow with difficulty at $45^{\circ} \mathrm{C}$ (COLEMAN et al. 1997a, 1997b, PINJON et al. 1998, SULlivan et al. 1997b, 1998, JABRA-RIZK et al. 1999a, MORSHHÄUSER et al. 1999). PINJON et al. (1998) found that only $1 \% \mathrm{C}$. albicans isolates failed to grow at $45^{\circ} \mathrm{C}$. However, KIRKPATRICK et al. (1998) observed that $36 \%$ C. albicans isolates did not grow at this temperature. This discrepancy could be a reflection of the inaccuracy of temperature readings and heat distribution in many laboratory incubators (SULLIVAN et al. 1999). This absence or restriction of growth is a simple and economic marker to demonstrate for $C$. dubliniensis, with the drawback that some atypical $C$. albicans isolates share the same characteristic (TINTELNOT et al. 2000).

A rapid and inexpensive way to presumptively differentiate between the two species after a previous germ tube test derives from the ability of $C$. dubliniensis to reduce the tetrazolium salt (VELEGRAKI and LOGOTHETI 1998). But TINTELNOT et al. (2000) have pointed out the limitations of a screening test based on the reduction in 2,3,5-triphenyltetrazolium chloride by $C$. dubliniensis and not by $C$. albicans, because this reduction is frequently seen with $C$. tropicalis isolates.

Although it is impossible to distinguish between $C$. albicans and $C$. dubliniensis colonies in conventional solid media, the introduction in the clinical microbiology laboratories of chromogenic agars, as CHROMagar Candida (CHROMAGAR Company, France) or Candida ID (BIOMÉRIEUX, France), has proven to be helpful in the identification of $C$. dubliniensis isolates, particularly following primary culture from clinical specimens. While C. albicans colonies are a light blue green color on CHROMAGAR Candida, $C$. dubliniensis colonies are a much darker green (particularly pronounced after $48 \mathrm{~h}$ ) (SCHOOFS et al. 1997, SULLIVAN and COLEMAN 1998, KOEHLER et al. 1999). CHROMagar Candida has been reformulated by BECTON DICKINSON (USA) and JABRA-RIZK et al. (2001) have observed on this reformulated agar lighter green colonies with $C$. albicans that made easier to differentiate between this species and C. dubliniensis. However, other authors (SCHOOFS et al. 1997, TINTELNOT et al. 2000) have reported that the ability of $C$. dubliniensis to produce dark green colonies can be lost with subculture and storage. For TINTELNOT et al. (2000) the color of the colonies on CHROMAGAR Candida proved to be insufficient for selecting this species, since only 30 of 53 proven $C$. dubliniensis isolates showed a dark green color in primary cultures. The reasons for this apparent colony color instability has yet to be elucidated but could be related to the higher frequency phenotype switching of $C$. dubliniensis isolates than C. albicans ones observed by HANNULA et al. (2000).

Recently, ODDS and DAVIDSON (2000) examined the color of colonies of nine Candida species on CHROMagar Candida incubated for $24-72 \mathrm{~h}$ at $25^{\circ} \mathrm{C}, 30^{\circ} \mathrm{C}$ or $37^{\circ} \mathrm{C}$. Colors and colony forms characteristic of $C$. albicans and C. dubliniensis were formed most rapidly and were best differentiated at $37^{\circ} \mathrm{C}$. They concluded that incubation of this chromogenic medium at temperatures below $30^{\circ} \mathrm{C}$ is not reliable for presumptive identification of Candida sp.

Other culture media, as Methyl blue-SABOURAUD agar (SCHOOF et al. 1997) or Candida ID agar (QUINDós et al. 2001), have been proposed for discriminating $C$. dubliniensis from C. albicans. On Methyl blue-SABOURAUD agar, C. albicans isolates produced yellow fluorescence when exposed to long-wave ultraviolet light, whereas $C$. dubliniensis isolates did not produce fluorescence. Unfortunately fluorescence was not visible in all C. albicans isolates when recovered from storage or repeated subcultures (SULLIVAN et al. 1998). On Candida ID agar, most $C$. dubliniensis isolates showed clear turquoise blue colonies, in contrast to $C$. albicans deep blue colonies. However, a small number of $C$. dubliniensis isolates grew as white colonies complicating their identification on this agar medium (QUINDós et al. 2001). 
Table 3

Identification of Candida dubliniensis with commercial yeast identification systems (reading at $48 \mathrm{H}$ )

\begin{tabular}{lll}
\hline Test name & Identification & Reference \\
\hline API 20C AUX & Good & GALES et al. (1999), PINCUS et al. (1999) \\
ATB ID 32C & Excellent & PINCUS et al. (1999), TINTELNOT et al. (2000), \\
& MOALIC et al. (2001) \\
RapidID Yeast Plus & Good & PINCUS et al. (1999) \\
Vitek YBC & Good & GALES et al. (1999), PINCUS et al. (1999) \\
VITEK 2 ID-YST card & Excellent & PINCUS et al. (1999), MOALIC et al. (2001) \\
\hline
\end{tabular}

From the earliest observations, $C$. dubliniensis has revealed significant differences with C. albicans on comparative analysis of substrate assimilation profiles using ATB ID 32C (BIOMÉrIeUX) and API 20C AUX systems (BIOMÉRIEUX) (PELTROCHE-LlaCsahuanga et al. 1999, SulliVAN et al. 1999). C. dubliniensis is unable to assimilate alpha-methyl-Dglucoside, lactate or xylose in contrast to the great majority of $C$. albicans isolates (SUlLivan et al. 1995, KIRKPATRICK et al. 1998, SALKIN et al. 1998). Moreover, C. dubliniensis grows more slowly than C. albicans when trehalose is used as the only source of carbon in culture medium. These differences in $C$. dubliniensis carbohydrate assimilation profiles have been included in the databases of ATB ID 32C and API 20C AUX. C.dubliniensis can also be accurately identified using a variety of other commercially available yeast identification techniques, including the Auxacolor (BIORAD, USA), API Candida (BIOMÉRIEUX), RapID Yeast Plus (REMEL, USA), VITEK YBC and VITEK 2 ID-YST (bioMérieux) systems (COLEMAN et al. 1993, GUTIÉRREZ et al. 1994a, 1994b, GALES et al. 1999, SUlLIVAN et al. 1999, WARREN and HAZEN 1999) (Table 3).

Two recent studies (GALES et al. 1999, PINCUS et al. 1999) have evaluated the usefulness of commercial systems for $C$. dubliniensis identification. GALES et al. (1999) studied the inability of this species to utilize xylose and alpha-methyl-D-glucoside by API 20C AUX and VITEK YBC systems and to grow poorly or not at all at $45^{\circ} \mathrm{C}$ as identification markers for $C$. dubliniensis. The authors observed that none of the $C$. dubliniensis isolates grew at $45{ }^{\circ} \mathrm{C}$, and $23 \%$ C. albicans isolates exhibited poor or no growth at this temperature. The xylose and alpha-methyl-D-glucoside tests contained within the API 20C AUX system were both negative for all $C$. dubliniensis isolates and were positive for $98 \%$ (xylose) and $56 \%$ (alpha-methyl-D-glucoside) of $C$. albicans isolates. With the VITEK system, 97\% $C$. $d u b$ liniensis isolates were xylose negative and $95 \%$ were alpha-methyl-D-glucoside negative. Conversely, $96 \%$ C. albicans isolates were xylose positive and $100 \%$ were alpha-methyl-Dglucoside positive. The authors concluded that lack of growth at $45{ }^{\circ} \mathrm{C}$ and a negative xylose test with either the API 20C AUX or VITEK yeast identification system could be used to provide a presumptive identification of $C$. dubliniensis, but a negative alpha-methyl-Dglucoside test result may misclassify $C$. albicans as $C$. dubliniensis, especially when the API 20C AUX system is used.

PINCUS et al. (1999), using similar and other commercial kits, evaluated the utility of assimilation of glycerol, lactate, alpha-methyl-D-glucoside, D-trehalose, and D-xylose by isolates of $C$. dubliniensis and C. albicans. At $48 \mathrm{~h}$ the assimilation of four carbohydrates in the API 20C AUX system could be used to distinguish them, i.e., glycerol (88 vs. 14\%), xylose (0 vs. 88\%), alpha-methyl-D-glucoside (0 vs. 85\%), and trehalose (15 vs. 97\%). Similarly, results with the ID $32 \mathrm{C}$ system at $48 \mathrm{~h}$ showed that xylose (0 vs. $98 \%)$, alpha-methylD-glucoside (0 vs. 98\%), lactate (0vs. 96\%), and trehalose (30vs. 96\%) could be used to separate both species. Phosphatase ( 9 vs. 76\%) and alpha-D-glucosidase (23 vs. 94\%) proved to be the most useful for separation of the species in the RapID Yeast Plus system. While at $24 \mathrm{~h}$ the profiles obtained with the VITEK YBC system showed that alpha-methyl- 
D-glucoside (10 vs. 95\%), xylose (0 vs. 95\%), and glycerol (26 vs. 80\%) could be used to separate the two species, at $48 \mathrm{~h}$ only xylose $(6 \mathrm{vs}$. 95\%) is useful to separate the two species. The most useful substrates in the VITEK 2 ID-YST system were trehalose (1 vs. 89\%), alpha-methyl-D-glucoside (1 vs. 99\%), lactate (4 vs. 98\%), and phosphatase (83 vs. 1\%). The authors underlined that the assimilation of alpha-methyl-D-glucoside, trehalose, and xylose proved to be the most useful for species differentiation by the majority of commercial systems. However, KURZAI et al. (2000) studying carbohydrate assimilation patterns for $C$. dubliniensis with a novel automated system observed that, in contrast to the previous reports, $C$. dubliniensis is able to utilize D-xylose and trehalose.

Another important difference between $C$. dubliniensis and $C$. albicans isolates is that the former cannot express beta-glucosidase activity. This feature was originally identified by multilocus enzyme electrophoresis and has been the basis of a reliable assay for the discrimination of both species (BOERLIN et al. 1995). It was observed that, in contrast with C. albicans, C. dubliniensis isolates did not produce beta-glucosidase activity. This led to the design of a simple method to differentiate between the two species based on the ability of $C$. albicans to generate fluorescence in the presence of methyl-umbelliferyl-labelled betaglucoside. This assay has been used to discriminate between $C$. dubliniensis and $C$. albicans in isolates from stock cultures (SULLIVAN et al. 1993, 1997, SULLIVAN and COLEMAN 1998), although in a recent analysis of an archival stock collection 67 of 537 (12.5\%) C. albicans isolates were found to be beta-glucosidase negative (Odds et al. 1998).

C. dubliniensis cells grown at $37^{\circ} \mathrm{C}$ on SABOURAUD dextrose agar have the ability to coaggregate in vitro with cells of the oral bacterium Fusobacterium nucleatum (JABRARISZK et al. 1999b, 1999c). C. albicans cells fail to coaggregate with this species at this temperature. These authors have developed a rapid, specific and inexpensive test using the strain ATCC 49256 of $F$. nucleatum to distinguish $C$. dubliniensis from $C$. albicans based on this phenomenon (JABRA-RIZK et al. 1999b, 1999c, BROWN et al. 2000).

BIKANDI et al. (1998) have developed a C. dubliniensis-specific antiserum adsorbed with C. albicans blastospores. This antiserum reacted with the blastospores of $C$. dubliniensis, but not with $C$. albicans blastospores. In a blind trial using an indirect immunofluorescence assay, the antiserum correctly discriminated between 83 C. dubliniensis and 43 C. albicans isolates. This test is very rapid and specific; however, its use is limited by the availability of the antiserum and by the immunofluorescence microscopy technique. A similar approach has been suggested by MAROT-LEBLOND et al. (2000) that have used hydrophobic components of the germ tube of the dimorphic pathogenic fungus $C$. albicans as immunogens to prepare monoclonal antibodies. Monoclonal antibody 16B1-F10 was shown to be specific to the surface of the mycelium phase of the $C$. albicans and may be a good candidate for use in immunological tests for the rapid differentiation of $C$. albicans and $C$. dubliniensis. The antigenic difference between both species (BIKANDI et al. 1998, MORAGUES et al. 2001) has been used for the diagnosis of a $C$. dubliniensis candidemia in an intravenous cocaine user detecting specific anti-C. dubliniensis antibodies by an indirect immunofluorescence and an immunoblotting assays (SALESA et al. 2000).

Other tests which allow the discrimination of $C$. dubliniensis and C. albicans include pyrolysis mass spectrometry and Fourier transform infrared spectroscopy (Timmins et al. 1998, TINTELNOT et al. 2000) which has shown a great reliability among the phenotypic methods.

Finally, we should mention the method developed by PELTROCHE-LLACSAHUANGA et al. (2000a) to discriminate between these two closely related yeast species by fatty acid methyl ester analysis using gas-liquid chromatography (Sherlock Microbial Identification System; MIDI Inc., USA). Although the chromatograms of these two species revealed no obvious differences when applying fatty acid methyl ester analysis, a new library (CADLIB) was created by the authors using SHERLOCK Library Generation Software (MIDI). Using this method, only $9.4 \%$ isolates of $C$. albicans were misidentified as $C$. dubliniensis, whereas all 
isolates of $C$. dubliniensis were correctly identified. Resulting differentiation accuracy was $90.6 \%$ for $C$. albicans and $100 \%$ for $C$. dubliniensis. However, the technology required to perform these techniques is not widely available at clinical diagnostic laboratories.

\section{Genotypic characteristics}

The identification methods based on phenotypic criteria may be subject to variable expression and lead to incorrect identification of isolates. A potentially more stable identification would be one based on the analysis of genetic variability. Genetic methods for Candida sp. Identification are currently limited to research usage and to date commercial kits have not become available. There are to traditional approaches for identification based on genetic variation, analyses of electrophoretic karyotype differences and restriction fragment length polymorphisms using gel electrophoresis or DNA-DNA hybridization (LOCKHART et al. 2001). Electrophoretic karyotype has progressed with the development of pulse field electrophoresis, which resolves DNA fragments over $50 \mathrm{~kb}$ by subjecting the DNA to an electrophoretic field that alternates in its direction (WILLIAMS and LEWIS 2000).

The first $C$. dubliniensis isolates were distinguished from $C$. albicans isolates because of their unusual DNA fingerprint patterns generated using the $C$. albicans-specific DNA fingerprinting probe 27A (SULLIVAN et al. 1993, 1995, 1996). The $C$. albicans-specific DNA fingerprinting probe 27A gives a classical fingerprinting pattern of 10-15 strongly hybridizing bands (with EcoR1-digested DNA) for C. albicans. On the contrary, the patterns of C. dubliniensis isolates comprised fewer and weaker bands (SULLIVAN et al. 1993, 1995, 1997b, 1998). Following pulsed-field gel electrophoresis of $C$. dubliniensis DNA, ten or more chromosome-sized DNA bands can be resolved, usually with one or more bands less than $1 \mathrm{Mb}$ in size (SULLIVAN et al. 1995, ANTHONY et al. 1995). In contrast, seven or eight bands are usually resolved in $C$. albicans.

The significant differences in the chromosomal arrangement of sequences in each species has been confirmed using a wide range of DNA profiling techniques, including fingerprinting with oligonucleotides homologous to microsatellite sequences, pulsed-field gel electrophoresis and specific or randomly amplified polymorphic DNA (RAPD) polymerase chain reaction (PCR) analysis (SULLIVAN et al. 1993, 1995, RUHNKE et al. 1997, 1999, BENNET et al. 1998, MetZGAR et al. 1998, DiAZ-GuERRA et al. 1999, IROBI et al. 1999, MORSCHHÄUSER et al. 1999, AlONSO-VARGAS et al. 2000, FUJITA et al. 2000, TAMURA et al. 2000) (Fig. 1). Karyotyping is time consuming, requiring approximately five days for DNA extraction and pulse field gel electrophoresis and costly specialized equipment for the latter, and only a limited number of samples can be included on each gel. These practical drawbacks limit the value of these methods as diagnostic tools in routine diagnostic microbiology laboratories (WILLIAMS and LEWIS 2000).

A quantitative measurement of the precise phylogenetic relationship between $C$. $d u b$ liniensis and $C$. albicans has been determined by comparing the evolutionarily conserved genes, as those encoding the ribosomal RNA (rRNA) (BOUCHER et al. 1996, HAYNES and WESTERNENG 1996). Alignment of gene sequences from the V3 region of the large rRNA subunit and from the entire small rRNA subunit with the corresponding sequences from different Candida species demonstrated that $C$. dubliniensis isolates belonged to a separate taxon (Sullivan et al. 1995, GILFILlan et al. 1998). Sullivan et al. (1995) found that a $600 \mathrm{bp}$ region encompassing the V3 variable region of the large rRNA (lrRNA) genes of C. dubliniensis and C. albicans differed by $2.3 \%$. Similar analysis of the D1/D2 region of the lrRNA genes of both species also revealed a significant degree of nucleotide divergence (MANNARELLI and KURTZMAN 1998). In addition, comparison of the sequence of the selfsplicing group I introns present in the lrRNA genes of both species revealed that the C. dubliniensis intron is almost identical to that of $C$. albicans except for two widely diver- 


\section{Lanes}

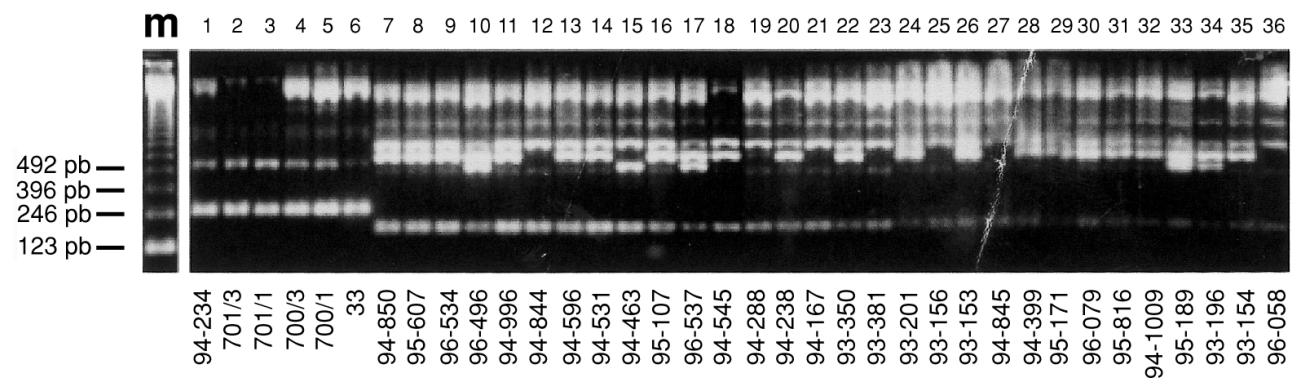

Fig. 1

RAPD fingerprinting patterns obtained withAB1.12 for Candida dubliniensis and Candida albicans clinical isolates. Lanes 1 to 6, C. dubliniensis isolates; Lanes 7 to 36, C. albicans; m, molecular weight marker -123 pb- (from AlONSO-VARGAS et al. (2000) with permission from authors and editor)

gent stem-loop regions (BOUCHER et al. 1996). The unique phylogenetic position of C. dubliniensis was further established by comparison of the sequences of the entire small rRNA genes (approximately $1.8 \mathrm{~kb}$ ) of $C$. dubliniensis and $C$. albicans that revealed a difference of $1.4 \%$ (GILFILLAN et al. 1998).

In addition to ribosomal RNA sequences, the $A C T 1$ gene, which encodes the structural protein actin, has been used extensively in phylogenetic studies. DONNELLY et al. (1999) have amplified from a recombinant phage isolated from a genomic DNA lambda library using PCR three overlapping fragments that together span the entire C. dubliniensis ACT1 gene $(C d A C T 1)$. These were cloned and used to determine the contiguous sequence of the gene. Comparison of the $C d A C T 1$ sequence with the $C$. albicans homologue $(C a A C T 1)$ revealed that although the exons are $97.9 \%$ identical the introns are only $83.4 \%$ identical. Phylogenetic trees generated using ACT1 exon and intron sequences from a range of yeast species unequivocally confirmed the phylogenetic position of $C$. dubliniensis as a unique taxon within the genus Candida. Analysis of the ACT1-associated intron sequences from 10 epidemiologically unrelated $C$. dubliniensis isolates from disparate geographical locations showed a very low level of intraspecies sequence variation. In order to develop an accurate and rapid method to identify $C$. dubliniensis from primary isolation plates the significant divergence between the $C$. dubliniensis and $C$. albicans ACT1 intron sequences was exploited by designing $C$. dubliniensis-specific PCR primers. Using a rapid boiling method to produce template DNA directly from colonies from primary isolation plates in $10 \mathrm{~min}$, these primers were used in a blind test with 122 isolates of $C$. dubliniensis, 63 isolates of C. albicans (including 10 isolates of $C$. albicans var. stellatoidea) and isolates of other clinically relevant yeast species. Only $C$.dubliniensis yielded the $C$.dubliniensis-specific 288 bp amplimer. Use of this technique on colonies suspected to be $C$. dubliniensis allows their correct identification as $C$. dubliniensis in as little as $4 \mathrm{~h}$.

MEYER et al. (2001) have proposed PCR fingerprinting using microsatellite ([GACA](4)) and minisatellite ([5'-GAGGGTGGCGGTTCT-3']), derived from the core-sequence of the wild-type phage M13 specific oligonucleotides as a simple, reliable and highly reproducible molecular tool to differentiate between strains of C.albicans and C. dubliniensis. C. albicans-specific primers have also been designed based on PHRI sequences that do not yield amplimers when used with $C$. dubliniensis template DNA (KURZAI et al. 1999). Restriction fragment length polymorphism analysis of amplimers obtained using PCR primers flanking various regions of the rRNA locus have also been demonstrated to allow the discrimination of C. dubliniensis from C. albicans (MCCULlOUGH et al. 1999). A PCR en- 
zyme immunoassay using a $C$. dubliniensis-specific DNA probe derived from the internal transcribed spacer 2 (ITS2) region of the rRNA locus has also been developed (ELIE et al. 1998). PARK et al. (2000) have used a DNA sequence analysis of the ITS2 region of rRNA genes from reference Candida strains to develop molecular beacon probes for rapid identification of $C$. dubliniensis and $C$. albicans. Molecular beacons are small nucleic acid probes that brightly fluoresce when bound to their targets with the significant advantage of a higher degree of specificity. When applied to an unknown collection of 23 C. albicans and $C$. dubliniensis isolates, the species-specific probes were $100 \%$ accurate in identifying both species following PCR amplification of the ITS2 region.

WILLIAMS et al. (2001) have examined sequence variations in the ribosomal DNA (rDNA) ITS regions of $C$. albicans and $C$. dubliniensis, with a view to identifying sequence differences that would enable consistent differentiation of these two species by restriction fragment length polymorphism analysis. The ITS1 and ITS2 regions, together with the entire 5.8S rRNA gene of the strains, were amplified by PCR, using primers ITS1 and ITS4. PCR products from both species were of similar size (around $540 \mathrm{bp}$ ). However, sequence analysis revealed over 20 consistent base differences between the products of the two species. On the basis of sequence variation, the restriction enzyme MspA1 I was selected and used to differentiate the PCR products by restriction fragment length polymorphisms analysis. MspA1 I yielded two discernible fragments from C. albicans PCR products. $C$. dubliniensis PCR products appeared undigested, providing an approach to differentiate the two species.

POSTERARO et al. (2000) developed a PCR-based assay to detect and identify medically important yeasts in clinical samples. The authors used a set of primers for amplifying a fragment of the ERG11 gene for cytochrome P-450 lanosterol 14-alpha-demethylase. The PCR product was analyzed in a reverse cross blot hybridization assay with species-specific probes directed to a target region of the ERG11 gene of C.albicans, C. dubliniensis, of other six medically important species of Candida, Saccharomyces cerevisiae, and Cryptococcus neoformans. The PCR-reverse cross blot hybridization assay correctly identified multiple isolates of each species tested and no cross-hybridization was detected with any other fungal, bacteria, or human DNAs tested. Species identification time was reduced from a mean of 4 days with conventional identification to $7 \mathrm{~h}$ with the molecular method.

YOKOYAMA et al. (2000) have sequenced a 396-bp region of the mitochondrial cytochrome B gene of the most common clinically important Candida species, including $C$. dubliniensis. Multiple alignments of nucleotide and deduced amino acid sequences revealed species-specific nucleotides and amino acids. Nucleotide- and amino acid-based phylogenetic trees were constructed and using the database, presumptive $C$. dubliniensis identification should be possible within a working day.

A species-specific repetitive DNA element $(\mathrm{Cd} 25)$ has been identified in $C$. dubliniensis which shows promise for use as a specific fingerprinting probe for this species and will aid in the epidemiological analysis of C. dubliniensis infections (JOLY et al. 1998). Cd25 can be a good probe since it is stable over time, is a truly $C$. dubliniensis specific probe, generates complex patterns, is distributed throughout all $C$. dubliniensis chromosomes, and has separated a worldwide collection of $57 \mathrm{C}$. dubliniensis isolates into two distinct groups. HANNULA et al. (2000) sought clonal differences among C. albicans and C. dubliniensis isolates recovered from patients with and without immunodeficiency. PCR amplification using the random sequence primer OPE-03 enabled grouping $C$. dubliniensis isolates in two genotypes (I and II) and C. albicans isolates in 15 genotypes (I-XV), but no significant difference was found by the authors in the distribution of genotypes between the patients with autoimmune polyendocrinopathy-candidiasis-ectodermal dystrophy and the healthy subjects.

Despite the advantages of PCR-based methods over classic phenotypic ones, the application of molecular techniques is relatively limited due to constraints of either technical staff 
training or in laboratory financing. However, PCR is being increasingly used within hospital laboratories for detection of human gene mutations, HLA typing, and viral diagnostics, and therefore it is possible that will be more widely used in the future (WILLIAMS and LEWIS 2000).

\section{Virulence}

At the cellular and molecular level, the 'commensal' Candida adopting a pathogenic behavior has to switch from a quiet way of life to a more complicated one to overcome the numerous human body barriers. Candida has to go through many steps to colonize and proliferate. Decrease in host defenses is not enough to explain invasion and infection and this fungus need a particular strategy to penetrate and grow within the human tissues (SENET 1997). Virtually nothing is known about the virulence factors of $C$. dubliniensis. However, it might be expected that this species may share the ability to produce certain putative virulence factors with C. albicans.

To switch from saprobe to pathogen, Candida develops some phenotypic characteristics, which allow adhesion and penetration. The tendency to change Candida behavior is very greats and in part depends on its environment. Candida has to overcome two main obstacles to be a successful pathogen, host mechanisms to interfere the adhesion of Candida to human tissues and the production of hydrolytic enzymes. Both processes are associated and related to morphological variations. The dimorphic transition in C. albicans from blastospore to the filamentous stage increases the adhesion and proteinase secretion. C.dubliniensis, as C. albicans, is dimorphic, but kinetics of hyphal production in C. dubliniensis looks slower than that observed for C. albicans (GILFILLAN et al. 1998). Hyphae are related to a higher adherence to cells and this may contribute to the apparent lower virulence of $C$. dubliniensis. But other characteristics are related to adherence and virulence in Candida as phenotypic switching, hydrolytic enzymes (as proteinases and phospholipases) production or hydrophobicity.

HANNUlA et al. (2000) have observed that C. dubliniensis isolates exhibited high frequency phenotypic switching significantly more frequently that $C$. albicans isolates did. This fact can be considered as a favorable factor for adaptation of this species to the host environment. C. dubliniensis possesses homologues of seven C. albicans secretory aspartyl proteinase genes $(S A P)$. An early study on five $C$. dubliniensis isolates suggested that these isolates produced higher levels of proteinase activity than reference isolates of $C$. albicans (MCCullough et al. 1995). Moreover, C. dubliniensis isolates were more adherent to buccal epithelial cells than the $C$. albicans strains tested (MCCULLOUGH et al. 1995, GILFILLAN et al. 1998). Secretory aspartyl proteinases have been proposed to play a role in adherence to tissue. The production of phospholipases in C. dubliniensis is strain-related and the amount produced shows important variations among clinical isolates and depending on the surrounding conditions (HANNULA et al. 2000). However, southern hybridization and PCR analyses have revealed that all $C$. dubliniensis isolates examined by BENNETT et al. (1998) possessed sequences homologous to $C$. albicans phospholipase $\mathrm{C} 1$ gene (CAPLC1).

Microbial adherence to mucosal surfaces is the first important step in the initiation of and invasive process in oral cavity and other human mucosae. C. albicans, the most adherent and pathogenic species of Candida, uses a diversity of mechanisms to adhere to human surfaces. The strongest mechanisms involve mannoprotein adhesins. Cell surface hydrophobicity plays also an important role in adherence by providing hydrophobic interactions that reinforce the initial bond between the fungal cell and the human surfaces (JABRA-RIZK et al. $2001 \mathrm{c})$. C. dubliniensis isolates seem to have a greater adherence to buccal epithelial cells than typical $C$. albicans strains and this is related to the hydrophobic interactions that facilitate adherence (MCCUllough et al. 1995, PEREIRO et al. 1997, GILFILlAN et al. 1998). Re- 
cent transmission electron microscopy studies (JABRA-RIZK et al. $2001 \mathrm{~b}$ ) have shown that C. dubliniensis, unlike $C$. albicans, displayed a constant outer fibrillar layer independent of growth temperature. The length and arrangement of cell fibrils were consistent with those observed in a hydrophobic cell phenotype (JABRA-RIZK et al. 1999). These data suggest that C. dubliniensis exhibits constant cell surface hydrophobicity.

Cell surface hydrophobicity status of $C$. albicans involves multiple surface proteins and surface protein $\mathrm{N}$-glycans. The hydrophobic surface glycoprotein CAgp38 appears to be expressed by $C$. albicans constitutively regardless of growth temperature and medium. C. dubliniensis expresses a $38-\mathrm{kDa}$ protein that cross-reacts with the anti-CAgp38 monoclonal antibody, expression that was growth medium and temperature dependent. The antiCAgp38 monoclonal antibody has been shown to inhibit adhesion of $C$. albicans to extracellular matrix proteins and to vascular endothelial cells. Similar bulk compositional levels of hexose, phosphate, and protein in their N-glycans were determined in both species. However, a component of the $C$. albicans $\mathrm{N}$-glycan, acid-labile phosphooligomannoside, is expressed much less or negligibly by $C$. dubliniensis, and when present, the oligomannosides are predominantly less than five mannose residues in length. For $C$. albicans, the acid-labile phosphooligomannoside influences virulence and surface fibrillar conformation, which affects exposure of hydrophobic surface proteins. Given the combined role in C. albicans of expression of specific surface hydrophobic proteins in pathogenesis and of surface protein glycosylation on exposure of the proteins, the lack of these virulence-associated cell surface hydrophobicity entities in $C$. dubliniensis could contribute to its limited ability to cause disseminated infections (MASUOKA and HAZEN 2000, HAZEN et al. 2001).

Candida must traverse the overlying mucus layer in order to approximate and adhere to mucosal epithelial cells (REPENTIGNY et al. 2000). Binding of the Candida species to purified small intestinal mucin showed a close correlation with their hierarchy of virulence. Significant differences $(\mathrm{P}<0.05)$ were found among three categories of Candida species adhering highly ( $C$. dubliniensis, C. tropicalis, and $C$. albicans), moderately ( $C$. parapsilosis and $C$. lusitaniae) or weakly (C. krusei and C. glabrata) to mucin. Adherence of C. albicans to buccal epithelial cells was quantitatively inhibited by graded concentrations of mucin. C. albicans may both adhere to and enzymatically degrade mucins by the action of proteases, and both properties may act to modulate Candida populations in the oral cavity and gastrointestinal tract.

C. dubliniensis grown at 25 or $37^{\circ} \mathrm{C}$ was shown to coaggregate with the oral anaerobic bacterium $F$. nucleatum (JABRA-RIZK et al. 2001b). However, C. albicans demonstrated similar coaggregation only when hydrophobic or grown at $25^{\circ} \mathrm{C}$. Coaggregation of Candida cells with $F$. nucleatum is associated with a hydrophobic yeast cell surface. All C. dubliniensis isolates tested grown at either temperature, hydrophobic $25^{\circ} \mathrm{C}$-grown C. albicans isolates, unlike the $37^{\circ} \mathrm{C}$-hydrophilic C. albicans isolates, exhibited hydrophobic cell surface hydrophobicity levels with a microsphere assay and a maximum coaggregation with $F$. nucleatum. Coaggregation reactions between $F$. nucleatum and Candida species may be important in the colonization of the yeast in the oral cavity. The binding of microorganisms to each other and oral surfaces contributes to the progression of microbial infections in the oral cavity. When C. dubliniensis and C. albicans strains were grown at $37^{\circ} \mathrm{C}$ on SABOURAUD dextrose agar, only $C$. dubliniensis strains coaggregated with $F$. nucleatum ATCC 49256 and no C. albicans strains showed coaggregation. Coaggregation at all growth temperatures was inhibited by mannose and alpha-methyl mannoside but not by EDTA or arginine. The coaggregation reaction between $F$. nucleatum and the Candida species involved a heat-labile component on $F$. nucleatum and a mannan-containing heat-stable receptor on the Candida species. KIRKPATRICK et al. (2000) have observed that $C$. albicans had a competitive advantage over $C$. dubliniensis in broth culture and under biofilm growing conditions. However, with the presence of a supporting structure for biofilm formation, as a 
denture or the microbial dental plaque, C. dubliniensis was able to better withstand the competitive pressures from $C$. albicans.

Cell surface hydrophobicity also plays a critical role in adhesion of microorganisms to phagocytic cells. Hydrophobic cells of $C$. albicans have been reported to be less sensitive to phagocytic killing than hydrophilic cells. $C$. dubliniensis displays cell surface hydrophobicity at $37^{\circ} \mathrm{C}$ in contrast to $C$. albicans. To elucidate this issue, Peltroche-LlaCsAhUANGA et al. (2000b) determined the levels of phagocytosis, oxidative burst and killing by human neutrophils of $C$. dubliniensis compared to $C$. albicans cultured at $37{ }^{\circ} \mathrm{C}$. Test results revealed no statistically significant differences between both species for the level of phagocytosis, evoked oxidative burst, and killing. The authors considered that human neutrophils are equally efficient against $C$. dubliniensis and $C$. albicans.

The $A L S$ (agglutinin-like sequence) gene family of $C$. albicans encodes cell-surface glycoproteins implicated in adhesion of the organism to host surfaces (HOYER et al. 2001). Southern blot analysis with $A L S$-specific probes suggested the presence of $A L S$ gene families in $C$. dubliniensis and $C$. tropicalis (three partial $A L S$ genes were isolated from each organism). Phylogenetic analysis of the $A L S$ and $S A P$ families show that the $A L S$ family is younger than the $S A P$ family. $A L S$ genes in $C$. albicans, $C$. dubliniensis, and $C$. tropicalis tend to be located on chromosomes that also encode genes from the $S A P$ family, yet the two families have unexpectedly different evolutionary histories (HOYER et al. 2001).

STAIB et al. (2000) have developed a system for the genetic transformation of C. dubliniensis that is based on the use of the dominant selection marker MPA(R) from C. albicans that confers resistance to mycophenolic acid. Using this transformation system, a green fluorescent protein reporter gene that was genetically engineered for functional expression in $C$. albicans and placed under control of the inducible C. albicans SAP2 promoter was integrated into the $C$. dubliniensis genome. Mycophenolic acid-resistant transformants containing the $S A P 2 P$-green fluorescent protein fusion fluoresced under $S A P 2$-inducing conditions but not under $S A P 2$-repressing conditions. These results demonstrate that the MPA(R) selection marker is useful for transformation of $C$. dubliniensis wild-type strains, that the green fluorescent protein reporter gene is functionally expressed in $C$. dubliniensis, and that the $C$. albicans $S A P 2$ promoter can be used for controlled gene expression in $C$. dubliniensis. These genetic tools will allow the dissection of the differences in virulence characteristics between the two pathogenic yeast species at the molecular level.

The only available published data from an animal model is equivocal. The in vivo virulence of four $C$. dubliniensis isolates and one reference $C$. albicans strain was tested in a systemic mouse model of infection. With an inoculum size of $2 \times 10^{6}$ cells per mouse the $C$. dubliniensis strains were clearly less virulent than the reference $C$. albicans strain. However, when the inoculum was increased to $1 \times 10^{7}$ cells per mouse the results were less clearcut. These data are clearly very preliminary and are based on limited numbers of strains. In addition, a systemic infection model is not ideal for the analysis of virulence of organisms implicated in meanly superficial infections (SULLIVAN et al. 1999).

\section{Antifungal susceptibility}

COLEMAN et al. (1997a) have suggested that the recent emergence of $C$. dubliniensis as a human pathogen may have resulted from selection due to the widespread use of antifungal drug therapy. However, the great majority of $C$. dubliniensis isolates are susceptible to common (amphotericin B, fluconazole, or itraconazole) and new antifungal agents (voriconazole, caspofungin, anidulafungin, ravuconazole or posaconazole) (Table 4) (MORAN et al. 1997, KIRKPATRICK et al. 1998, OdDS et al. 1998, PFALlER et al. 1999, QUINDÓS et al. 2000, RUESGA et al. 2000). 
In a recent study (PFALLER et al. 1999) using the NCCLS M27-A broth dilution method (1997), approximately $97 \%$ C. dubliniensis isolates were susceptible in vitro to fluconazole, the most commonly used agent in the treatment of candidiasis. Isolates with dose-dependent Table 4

In vitro antifungal susceptibilities of Candida dubliniensis clinical isolates

\begin{tabular}{|c|c|c|}
\hline Antifungal agent & In vitro & susceptibilityReference \\
\hline 5-fluorocytosine & Excellent & PFALLER et al. (1999), Quindós et al. (2000) \\
\hline Amphotericin B & Excellent & $\begin{array}{l}\text { KIRKPATRICK et al. (1998), PFALLER et al. } \\
\text { (1999), QUINDÓS et al. (2000) }\end{array}$ \\
\hline Anidulafungin & Good & QUINDÓs et al. (2000) \\
\hline Caspofungin & Excellent & PFALLER et al. (1999), RUESGA et al. (2000) \\
\hline Clotrimazole & Excellent & TORRES-RODRÍGUEZ et al. (1999) \\
\hline Eberconazole & Excellent & TORRES-RODRÍGUEZ et al. (1999) \\
\hline Fluconazole & Good (Decreased) & $\begin{array}{l}\text { MORAN et al. (1997), JABRA-RIZK et al. (1999), } \\
\text { QUINDÓS et al. (2000), RUHNKE et al. (2001) }\end{array}$ \\
\hline Itraconazole & Good, (Decreased) & $\begin{array}{l}\text { PFALLER et al. (1999), QUINDÓs et al. (2000), } \\
\text { RUHNKE } \text { et al. (2001) }\end{array}$ \\
\hline Ketoconazole & Good (Decreased) & $\begin{array}{l}\text { TORRES-RODRÍGUEZ et al. (1999), QUINDÓs et al. } \\
\text { (2000) }\end{array}$ \\
\hline Lipidic Amphotericin B & Excellent & QUINDÓs et al. (2000) \\
\hline Liposomal, Nystatin & Excellent & QUINDÓs et al. (2000) \\
\hline Posaconazole & Excellent & PFAller et al. (1999), RUESGA et al. (2000) \\
\hline Ravuconazole & Excellent & PfAlleR et al. (1999), RUESGa et al. (2000) \\
\hline Terbinafine & Excellent & RYDER et al. (1998) \\
\hline Voriconazole & Excellent & $\begin{array}{l}\text { KIRCKPATRICK et al. (1998), PFALLER et al. } \\
\text { (1999), QUINDÓs et al. (2000) }\end{array}$ \\
\hline
\end{tabular}

Lipidic amphotericin B, Amphotericin B colloidal dispersion, Amphotericin B lipid complex, and Liposomal amphotericin B.

susceptibility (MIC $16-32 \mu \mathrm{g} / \mathrm{ml}$ ) or resistance (MIC $\geq 64 \mu \mathrm{g} / \mathrm{ml}$ ) to this azole agent has been described (KIRKPATRICK et al. 1998, MORAN et al. 1997, ODDS et al. 1998, QUINDÓs et al. 2000). The comparison of the geometric mean MICs for fluconazole, itraconazole and ketoconazole of 58 clinical isolates each of $C$. albicans and $C$. dubliniensis revealed that the MIC values of $C$. dubliniensis isolates were significantly and consistently higher than those of the C. albicans ones (ODDS et al. 1998). QUINDÓS et al. (2000) described four isolates resistant to fluconazole that were also resistant to ketoconazole, and three of them were also resistant to itraconazole. However, these isolates were highly susceptible to 5-fluorocystosine, amphotericin B and nystatin lipidic formulations, posaconazole and voriconazole and anidulafungin.

Moreover, the simple fact of growing colonies on agar medium containing sequentially increasing concentrations of fluconazole results in the development of resistance (MORAN et al. 1997). This ability of $C$. dubliniensis to generate resistant to fluconazole derivatives may be a significant factor of ecological adaptation, giving them a selective advantage in patients treated extensively with fluconazole and having therapeutic consequences in HIVinfected patients (SULLIVAN et al. 1999). Recently, RUHNKE et al. (2001) have described the case of a patient with recurrent episodes of oral candidiasis that finally suffered from fluconazole-refractory oral and esophageal candidiasis. The patient was monitored for 4 years, showing a persistent colonization by both $C$. albicans and $C$. dubliniensis. From the first episode of candidiasis, the patient was treated with fluconazole becoming unresponsive to $400 \mathrm{mg} /$ day. In vitro susceptibility testing revealed the development of resistance to flu- 
conazole in both species. Molecular typing confirmed the persistence of the same C. albicans and $C$. dubliniensis strains. This observation could demonstrate that $C$. dubliniensis develops resistance to fluconazole in patients repeatedly exposed to this antifungal drug.

Analysis of the resistance mechanisms in both clinical and in vitro-generated resistant organisms has revealed that overexpression of the major facilitator protein Mdr1p appears to be largely responsible for the resistance phenotype (MORAN et al. 1998). This is in contrast to the situation in $C$. albicans where it has been suggested that overexpression of the ABC transporter protein Cdr1p is a more common mechanism of fluconazole-resistance (SANGLARD et al. 1995, ALBERTSON et al. 1996, SULLIVAN et al. 1999, STAIB et al. 2001).

\section{References}

Albertson, G., Niimi, M., Cannon, R. D. and Jenkison, H. F., 1996. Multiple efflux mechanisms are involved in Candida albicans fluconazole resistance. Antimicrob. Agents Chemother., 40, $2835-2841$.

Al-Mosaid, A., Sullivan, D., Salkin, I. F., Shanley, D. and Coleman, D. C., 2001. Differentiation of Candida dubliniensis from Candida albicans on Staib agar and caffeic acid-ferric citrate agar. J. Clin. Microbiol., 39, 323-327.

Alonso-VArgas, R., Garaizar, J., Pontón, J. and Quindós, G., 2000. Utility of random amplified polymorphic DNA in the discrimination between Candida albicans and Candida dubliniensis. Rev. Iberoam. Micol., 17, 10-13.

Alves, S. H., Milan, E. P., Moretti-Branchini, M. L., Nishimura, K., Fukushima, K., Oliveira, L. O., Costa, J. M. and Colombo, A. L., 2001. First isolation of Candida dubliniensis in Rio grande do sul, Brazil. Diagn. Microbiol. Infect. Dis., 39, 165-168

Anthony, R., Midgley, J., Sweet, S. and Howel S., 1995. Multiple strains of Candida albicans in the oral cavity of HIV positive and HIV negative patients. Microb. Ecol. Health. Dis., 8, 23-30.

Badoc, C., Bertout, S., Mallié, M. and Bastide, J. M., 2001. Genotype identification of Candida dubliniensis isolated from HIV patients by MLEE. Med. Mycol., 39, 117-122.

BENNET, D. E., 1998. Genetic characterization of phospholipase C gene from Candida albicans, presence of Homologous sequences in Candida species other than Candida albicans. Microbiology., 144, 55-72.

Bikandi, J., San Millán, R., Moragues, M. D., Cebas, G., Clarke, M., Coleman, D. C., SulliVAN, D. J., Quindós, G. and PonTón, J., 1998. Rapid identification of Candida dubliniensis by indirect immunofluorescence based on differential localization of antigens on $C$. dubliniensis blastospores and Candida albicans germ tubes. J. Clin. Microbiol., 36, 2428-2433.

Boerlin, P., Boerlin-Petzold, F., Durussel, C., Addo, M., Pagani, J. L., Chave, J. P. and Bille, J., 1995. Cluster of atypical Candida isolates in a group of Human immunodeficiency virus positive drug users. J. Clin. Microbiol., 33, 1129-1135.

Boucher, H., Mercure, S., MontPlaisir, S. and Lemay, G., 1996. A novel group I intron in $C$. dubliniensis is homologous to C. albicans intron. Gene, 180, 189-196.

Brandt, M. E., Harrison, L. H., Pass, M., Sofair, A. N., Huie, S., LI, R. K., Morrison, C. J., WARNOCK, D. W. and HAJJEH, R. A., 2000. Candida dubliniensis fungemia, the first four cases in North America. Emerg. Infect. Dis., 6, 46-49.

Brown, D., Jabra-RizK, M. A., Falkler, W. A., Baqui, A. A. and Meiller T., 2000. Identification of C. dubliniensis in a study of HIV seropositive pediatric dental patients. Pediatr. Dent., 22, 234238.

Ceballos, A., Gaitán, L. A., Ruesga, M. T., Ceballos, L. and Quindós, G., 1998. Prevalence of oral lesions by Candida sp., Their varieties and serotypes in a population of patient with AIDS under a Highly active antiretroviral therapy. Rev. Iberoam. Micol., 15, 141-145.

Coleman, D., Bennett, G. P., Sullivan, D., Gallagher, P., Henman, M. and Shanley, D., 1993. Oral Candida in HIV infection and AIDS, new perspectives new approaches. Crit. Rev. Microbiol., 9, 61-82. 
Coleman, D., Sullivan, D., Bennet, G. P., Moran, G., Barry, H. and Shaley, D., 1997 a. Candidiasis, the emergence of a novel species, Candida dubliniensis. AIDS, 11, 557-567.

Coleman, D., Sullivan, D., Hayens, M., Henman, M., Shanley, D., Bennet, D., 1997b. Molecular and phenotypic analysis of Candida dubliniensis, a recently identified species linked with oral candidiasis in HIV-infected and AIDS patients. Oral Dis, 3, 96-101.

Coleman, D. C., Rinaldi, M. G., Haynes, K. A., ReX, J. H., Summerbell, R. C., Anaissie, E. J., Li, A. and Sullivan, D. J., 1998. Importance of Candida species other than Candida albicans as opportunistic pathogens. Med. Mycol., 36 (Suppl.1), 156-165.

Coleman, D. C., Sullivan, D. J. and Mossman, J. M., 1997c. Candida dubliniensis. J. Clin. Microbiol., 35, 3011-3012.

Díaz, T., Mellado, E., Cuenca, M., Laguna, F. and Rodríguez, J., 1999. Molecular characterization by PCR-fingerprinting of $C$. dubliniensis strains isolated from two HIV-positive patients in Spain. Diagn. Microbiol. Infect. Dis., 35, 113-119.

Donnelly, S. M., Sullivan, D. J., Shanley, D. B. and Coleman, D. C., 1999. Phylogenetic analysis and rapid identification of Candida dubliniensis based on analysis of ACT1 intron and exon sequences. Microbiology, 145, 1871-1882.

Elie, C. M., LotT, T. J., ReIss, E. and Morrison, C. J., 1998. Rapid identification of Candida species with species-specific DNA probes. J. Clin. Microbiol., 36, 3260-3265.

Fujita, S. and HASHIMOTO, T., 2000. DNA fingerprinting patterns of Candida species using HinfI endonuclease. Int. J. Syst. Evol. Microbiol., 50, 1381-1389.

Gales, A. C., Pfaller, M. A., Houston, A. K., Joly, S., Sullivan, D. J., Coleman, D. C. and Soll, D. R., 1999. Identification of Candida dubliniensis based on temperature and utilization of xylose and alpha-methyl-D-glucoside as determined with the API 20C AUX and Vitek YBC Systems. J. Clin. Microbiol., 37, 3804-3808.

Giammanco, G. M., Pignato, S., Salvo, S. and Giammanco, G., 2000. Carbohydrate assimilation profiles of the first Italian Candida dubliniensis clinical isolates recovered from an HIV-infected individual. Res. Microbiol., 151, 889-891.

Gilfillan, G. D., Sullivan, D. J., Haynes, K., Parkinson, T., Coleman, D. C. and Gow, N. A. R., 1998. Candida dubliniensis, phylogeny and putative virulence factors. Microbiology, 144, 829838.

Gutiérrez, J., Martín, E., Lozano, C., Coronilla, J. and Nogales, C., 1994 a. Evaluation of the ATB 32 C, automicrobic system and API 20C using clinical yeast isolates. Ann. Biol. Clin., 50, $443-446$.

GutierreZ, J. and De La Higuera, A., 1994b. Microbiological diagnosis of fungal endocarditis. Clin. Adv. Treat. Fungal Infect., 5, 4-11.

Hannula, J., SaArela, M., Dogan, B., Paatsama, J., Koukila-Kahkola, P., Pirinen, S., AlaKomi, H. L., Perheentupa, J. and Asikainen, S., 2000. Comparison of virulence factors of oral Candida dubliniensis and Candida albicans isolates in Healthy people and patients with chronic candidosis. Oral Microbiol. Immunol., 15, 238-244.

HAYNES, K. A. and Westerneng, T. J., 1996. Rapid identification of Candida albicans, C. glabrata, C. parapsilosis and C. krusei by species-specific PCR of large subunit ribosomal DNA. J. Med. Microbiol., 44, 390-396.

Hazen, K. C., Wu, J. G. and Masuoka, J., 2001. Comparison of the Hydrophobic properties of Candida albicans and Candida dubliniensis. Infect. Immun., 69, 779-786.

Hoyer, L. L., Fundyga, R., Hecht, J. E., Kapteyn, J. C., Klis, F. M. and Arnold, J., 2001. Characterization of agglutinin-like sequence genes from non-albicans Candida and phylogenetic analysis of the $A L S$ family. Genetics, 157, 1555-1567.

Irobi, J., SCHOOFS, A. and Goossens, H., 1999. Genetic identification of Candida species in HIVpositive patients using the polymerase chain reaction and restriction fragment length polymorphism analysis of its DNA. Mol. Cell Probes, 13, 401-406.

Jabra-Rizk, M. A., Baqui, Aama, Kelley, J. I., Falkler, W. A. Jr, Merz, W. G. and Meiller, T. F., 1999a. Identification of Candida dubliniensis in a prospective study of patients in the United States. J. Clin. Microbiol., 37, 321-326.

Jabra-Rizk, M. A., Brenner, T. M., Romagnoli, M., Baqui, Aama, Merz, W. G., Falkler, W. A. and MeILlER, T. F., 2001a. Evaluation of a reformulated CHROMagar Candida. J. Clin. Microbiol., 39, 2015-2016. 
Jabra-Rizk, M. A., Falkler, W. A. Jr, Merz, W. G., Baqui, Aama, Kelley, J. I. and Meiller, T. F., 2001 b. Cell surface Hydrophobicity-associated adherence of Candida dubliniensis to Human buccal epithelial cells. Rev. Iberoam. Micol., 18, 17-22.

Jabra-Rizk, M. A., Falkler, W. A. Jr, Merz, W. G., Baqui, Aama, Kelley, J. I. and Meiller, T. F., 2000. Retrospective identification of Candida dubliniensis among Candida albicans clinical laboratory isolates from HIV and non-HIV individuals. J. Clin. Microbiol., 38, 2423-2426.

Jabra-Rizk, M. A., Falkler, W. A. Jr, Merz, W. G., Kelley, J. I., Baqui, Aama and Meiller, T. F., 1999b. Coaggregation of Candida dubliniensis and Candida albicans display surface variation consistent with observed intergeneric coaggregation. Rev. Iberoam. Micol., 16, 187-193.

Jabra-Rizk, M. A., Falkler, W. A. Jr, Merz, W. G., Kelley, J. I., Baqui, Aama and Meiller, T. F., 1999c. Coaggregation of Candida dubliniensis with Fusobacterium nucleatum. J. Clin. Microbiol., 37, 1464-1468.

Jabra-Rizk, M. A., Falkler, W. A., Merz, W. G. and Meiller, T. F., 2001c. New assay for measuring cell surface hydrophobicities of Candida dubliniensis and Candida albicans. Clin. Diagn. Lab. Immunol., 8, 585-587.

Joly, S., Pujol, C., Rysz, M., VArgas, K. and Soll, D. R., 1999. Development and characterization of complex DNA fingerprinting probes for the infectious yeast Candida dubliniensis. J. Clin. Microbiol., 37, 1035-1044.

Kamei, K., Mccullough, M. J. and Stevens, D. A., 2000. Initial case of Candida dubliniensis infection from Asia, non-mucosal infection. Med. Mycol., 38, 81-83.

KirkPatrick, W. R., LÓPez-Ribot, J. L., McAtee, R. K. and Patterson, T. F., 2000. Growth competition between Candida dubliniensis and Candida albicans under broth and biofilm growing conditions. J. Clin. Microbiol., 38, 902-904.

Kirkpatrick, W. R., Revankar, S. G., McAtee, R. K., López-Ribot, J. L., Fothergill, A. W., McCarthy, D. I., Sanche, S. E., Cantu, R. A., Rinaldi, M. G. and Patterson, T. F., 1998. Detection of Candida dubliniensis in oropharyngeal samples from human immunodeficiency virusinfected patients in North America by primary CHROMagar Candida screening and susceptibility testing of isolates. J. Clin. Microbiol., 36, 3007-3012.

Koehler, A. P., Chu, K. C., Hounang, E. T. S. and Cheng, A. F. B. 1999. Simple, reliable, and costeffective yeast identification scheme for the clinical laboratory. J. Clin. Microbiol., 37, 422-426.

Kurzai, O., Heinz, W. J., Sullivan, D. J., Coleman, D. C., Frosch, M. and Muhlschlegel, F. A., 1999. Rapid PCR test for discriminating between Candida albicans and Candida dubliniensis isolates using primers derived from the $\mathrm{pH}$-regulated PHR1 and PHR2 genes of Candida albicans. J. Clin. Microbiol., 37, 1587-1590.

Kurzai, O., Korting, H. C., Harmsen, D., Bautsch, W., Molitor, M., Frosch, M. and MuhlSCHLEGEL, F. A., 2000. Molecular and phenotypic identification of the yeast pathogen Candida dubliniensis. J. Mol. Med., 78, 521-529.

Lefler, E., Mccullough, M. J., Clemons, K. V. and Stevens, D. A., 2001. Initial isolation of Candida dubliniensis from the Middle East. Int. J. Infect. Dis., 5, 40-42.

Lockhart, S. R., Pujol, C., Joly, S. and Soll, D. R., 2001. Development and use of complex probes for DNA fingerprinting the infectious fungi. Med. Mycol., 39, 1-8.

Mannarelli, B. M. and KuRtzman, C. P., 1998. Rapid identification of Candida albicans and other human pathogenic yeast by using short oligonucleotides in a PCR. J. Clin. Microbiol., 36, 16341641.

Marot-Leblond, A., Grimaud, L., Nail, S., Bouterige, S., Apaire-Marchais, V., Sullivan, D. J. and Robert, R., 2000. New monoclonal antibody specific for Candida albicans germ tube. J. Clin. Microbiol., 38, 61-67.

Marriott, D., LaXton, M. and Harkness, J., 2001. Candida dubliniensis candidemia in Australia. Emerg. Infect. Dis., 7, 479.

MasuoKa, J. and HAZEN, K. C., 2000. Comparison of C. albicans and C. dubliniensis cell wall mannan and cell surface hydrophobicity. Glycobiology, 10, 1123.

McCullough, M., Ross, B. and ReAde, P., 1995. Characterization of genetically distinct subgroup of Candida albicans strains isolated from oral cavities of patients infected with human immunodeficiency virus. J. Clin. Microbiol., 33, 696-700.

McCullough, M. J., Clemons, K. V. and Stevens, D. A., 1999. Molecular and phenotypic characterization of genotype Candida albicans subgroups and comparison with Candida dubliniensis and Candida stellatoidea . J. Clin. Microbiol., 37, 417-421. 
Meis, J. F., Rhunke, M., De Pauw, B. E., Odds, F. C., Siegert, W. and Verweid, P. E., 1999. Candida dubliniensis candidemia in patients with chemotherapy induced neutropenia and bone marrow transplantation. Emerg Infect Dis., 5, 150-153.

MetzGar, D., Field, D., Haubrich, R. and Wills, C., 1998. Sequence analysis of a compound coding-region microsatellite in Candida albicans resolves homoplasies and provides a high-resolution tool for genotyping. FEMS Immunol. Med. Microbiol., 20, 103-109.

Meiller, T. F., Jabra-Rizk, M. A., Baqui, A. A., Kelley, J. I., Meeks, V. I., Merz, W. G. and FALKLER, W. A., 1999. Oral Candida dubliniensis as a clinically important species in HIVseropositive patients in the United States. Oral Surg. Oral Med. Oral Pathol. Oral Radiol. Endod., 88, 573-580.

Meyer, W., Maszewska, K. and Sorrel, T. C., 2001. PCR fingerprinting, a convenient molecular tool to distinguish between Candida dubliniensis and Candida albicans. Med. Mycol., 39, 185193.

Moalic, V., Moalic, E., Bellein, V., Jezequel, J., Garre, M., Berthou, C. and Le-Flohic, A. M., 2001. First identification of Candida dubliniensis in the Brest University Hospital (France). J. Mycol. Med., 11, $32-37$

Moragues, M. D., OmaetXebarkia, M. J., Elguezabal, N., Bikandi, J., Quindós, G., Coleman, D. C. and PonTón, J., 2001. Serological differentiation of experimentally induced Candida dubliniensis and Candida albicans infections. J. Clin. Microbiol., 39, 2999-3001.

Moran, G. P., Sanglard, D., Donnelly, S. M., Shanley, D. B., Sullivan, D. J. and Coleman, D. C., 1998. Identification and expression of multidrug transporters responsible for fluconazole resistance in Candida dubliniensis. Antimicrob. Agents Chemother., 42, 1819-1830.

Moran, G. P., Sullivan, D. J., Henman, M. C., McCreary, C. E., Harrington, B. J., Shanley, D. B. and Coleman, D. C., 1997. Antifungal drug susceptibilities of oral Candida dubliniensis isolates from human immunodeficiency virus (HIV)-infected and non-HIV-infected subjects and generation of stable fluconazole-resistant derivatives in vitro. Antimicrob. Agents Chemother., 41, $617-623$

MorschHÄUSer, J., Ruhnke, M., Michel, S. and HACKer, J., 1999. Identification of CARE-2 negative Candida albicans isolates as Candida dubliniensis. Mycoses, 42, 29-32.

National Committee For Clinical Laboratory Standars, 1997. Reference method for broth dilution antifungal susceptibility testing of yeast, approved standard M27-A, National Committee or Clinical Laboratory Standards, Wayne, Pa.

OdDS, F. C. and DAVIDSON, A., 2000. "Room temperature" use of CHROMagar Candida. Diagn. Microbiol. Infect. Dis., 38, 147-150.

OdDS, F. C., Nuffel, L. V. and DAms G., 1998. Prevalence of Candida dubliniensis isolates in a yeast stock collection. J. Clin. Microbiol., 36, 2869-2873.

Park, S., Wong, M., Marras, S. A., Cross, E. W., Kiehn, T. E., Chaturvedi, V., Tyagi, S. and PERLIN, D. S., 2000. Rapid identification of Candida dubliniensis using a species-specific molecular beacon. J. Clin. Microbiol., 38, 2829-2836.

Peltroche-Llacsahuanga, H., Schmidt, S., Seibold, M., Lutticken, R. and HaAse, G., 2000a. Differentiation between $C$. dubliniensis and $C$. albicans by fatty acid methyl ester analysis using gas liquid chromatography. J. Clin. Microbiol., 38, 3696-3704.

Peltroche-Llacsahuanga, H., Schnitzler, N. , Schmidt, S.,Tintelnot, K. , Lutticken, R. and HAASE, G., 2000b. Phagocytosis, oxidative burst, and killing of Candida dubliniensis and Candida albicans by human neutrophils. FEMS Microbiol. Lett., 191, 151-155.

Peltroche-Llacsahuanga, H., Schnitzler, N., Lutticken, R. and HaAse, G., 1999. Rapid identification of Candida glabrata by using dipstick to detect trehalase-generated glucose. J. Clin. Microbiol., 37, 202-205.

Pereiro, M. Jr, LosadA, A. and Toribio, J., 1997. Adherence of Candida albicans strains isolated from AIDS patients. Comparison with pathogenic yeast isolated from patients without infection. Br. J. Dermatol., 137, 76-80

Pfaller, M., Messer, S., Gee, S., Joly, S., Pujol, C. and Sullivan, D., 1999. In vitro susceptibilities of Candida dubliniensis isolates tested against the new triazole and echinocandin antifungal agents. J. Clin. Microbiol., 37, 870-872.

Pijon, E., Sullivan, D., Salkin, I., Shanley, D. and Coleman, D. C., 1998. Simple inexpensive, reliable method for differentiation of Candida dubliniensis from Candida albicans. J. Clin. Microbiol., 6, 2093-2095. 
Pincus, D. H., Coleman, D. C., Pruitt, W. R., Padhye, A. A., Salkin, I. F., Geimer, M., Bassel, A., Sullivan, D. J., Clarke, M. and Heran, V., 1999. Rapid identification of Candida dubliniensis with commercial yeast identification systems. J. Clin. Microbiol., 37, 3533-3539.

Polacheck, I., Strahilevitz, J., Sullivan, D., Donnelly, S., Salkin, I. F. and Coleman, D. C., 2000. Recovery of Candida dubliniensis from non human immunodeficiency virus infected patients in Israel. J. Clin. Microbiol., 38, 170-174.

Pontón, J., Rüchel, R., Clemons, K. V., Coleman, D. C., Grillot, R., Guarro, J., Aldebert, D., Ambroise-Thomas P., Cano, J., Carrillo-Muñoz A. J., Gené, J., Pinel, C. and Stevens, D. A., 2000. Emerging pathogens. Med. Mycol., 38 (Suppl. 1), 225-236.

Posteraro, T., Sanguinetti, M., Masucci, L., Romano, L., Morace, G. and Fadda, G., 2000. Reverse cross blot Hybridization assay for rapid detection of PCR-amplified DNA from Candida species, Cryptococcus neoformans and Saccharomyces cerevisiae in clinical samples. J. Clin. Microbiol., 38, 1609-1614.

Pujol, C., Renaud, F., Mallie, M., De Meeus, T. and Bastide, J. M., 1997. Atypical strains of Candida albicans recovered from AIDS patients. J. Med. Vet. Mycol., 35, 115-121.

Quindós, G., Alonso-Vargas, R., Helou, S., Arechavala, A., Martín-Mazuelos, E. and NeGRONI, R., 2001. Evaluación micológica de un nuevo medio de cultivo cromógeno (Candida ID ${ }^{\circledR}$ ) para el aislamiento e identificación presuntiva de Candida albicans y otras levaduras de interés médico. Rev. Iberoam. Micol., 18, 23-28.

Quindós, G., Carrillo-Muñoz, A. J., Arévalo, M. P., Salgado, J, Alonso-Vargas, R., Rodrigo, J. M., Ruesga, M. T., Valverde, A., Pemán, J., Cantón, E., Martín-Mazuelos, E. and PONTÓN, J., 2000. In vitro susceptibility of Candida dubliniensis to current and new antifungal agents. Chemotherapy, 46, 395-401.

Redding, S. W., Bailey, C. W., Lopez-Ribot, J. L., Kirkpatrick, W. R., Fothergill, A. W., RiNALDI, M. G. and PATTERSON, T. F., 2001. Candida dubliniensis in radiation-induced oropharyngeal candidiasis. Oral Surg. Oral Med. Oral Pathol. Oral Radiol. Endod., 91, 659-662

Repentigny, L., Aumont, F., Bernard, K. and Belhumeur, P., 2000. Characterization of binding of Candida albicans to small intestinal mucin and its role in adherence to mucosal epithelial cells. Infect. Immun., 68, 3172-3179.

Rodero, L., Losso, M., Canteros, C., Hochenfellner, F. and Davel, G., 1998. Candida dubliniensis, $1^{\text {st }}$ isolation in Argentina. Rev. Arg. Microbiol., 10, 39-41.

RuesGa, M. T., Quindós, G. and LÓPEZ-Ribot, J. L., 2000. Azole and echinocandin antifungal agents against Candida species. Rev. Iberoam. Micol., 17, S160.

Ruhnke, M., Grosch-Worner, I., Lischewski, A., Neubauer, A., Steinmuller, A., Trautmann, M. and MORSCHHÄUSER J., 1999. Genotypic relatedness of yeast isolates from women infected with Human immunodeficiency virus and their children. Mycoses, 42, 385-394.

Ruhnke, M., Grosh-Worner, I., Steinmuller, A. and Neubauer, A., 1997. Molecular epidemiology of Candida infections in HIV-infected mothers and their offspring. Wien. Med. Wochenschr., 147, 446-449.

RuhnKe, M., Schmidt-Westhausen, A. and MorschHÄUSER, J., 2001. Development of simultaneous resistance to fluconazole in Candida albicans and Candida dubliniensis in a patient with AIDS. J. Antimicrob. Chemother., 46, 291-295.

RYDER, N. S, WAGNER, S. and LEITNER I., 1998. In vitro activities of terbinafine against cutaneous isolates of Candida albicans and other pathogenic yeast. Antimicrob. Agents Chemother., 42, 10571061.

Salesa, R., Moragues, M. D., Sota, R., Pemán, J., Quindós, G. and Pontón, J., 2001. Specific antibody response in a patient with Candida dubliniensis fungemia. Rev. Iberoam. Micol., 18, 42-44.

Salkin, I. F., Pruitt, W. R., Padhye, A. A., Sullivan, D., Coleman, D. and Pincus, D. H., 1998. Distinctive carbohydrate assimilation profiles used to identify the first clinical isolates of $C$. $d u b$ liniensis recovered in the United States. J. Clin. Microbiol., 36, 1467

SANDVEN, P., 2000. Epidemiology of candidemia. Rev. Iberoam. Micol., 17, 73-81.

Sanglard, D., Kuchler, K., Ischer, F., Pagani, J., Monod, M. and Bille, J., 1995. Mechanism of resistance to azole antifungal agents in Candida albicans isolates from AIDS patients involve specific multidrug transporter. Antimicrob. Agents Chemother., 39, 2378-2386.

Sano, A., Vilela, M. M., Takahashi, I., Fukushima, K., Takizawa, K., Da Silva, M. T., Uno, J., NishimuRA, K. and MiYAJI, M., 2000. Isolation of Candida dubliniensis from the oral cavity of an HIV-positive child in Brazil. Nippon Ishinkin Gakkai Zasshi., 41, 177-81. 
Schoofs, A., Odds, F. C., Colebunders, R., Leven, M. and Goosens, H., 1997. Use of specialized isolation media for recognition and identification of Candida dubliniensis isolates from VIHinfected patients. Eur. J. Clin. Infect Dis., 16, 296-300.

Schorling, S. R., Kortinga, H. C, Froschb, M. and Mulhschlegel, F. A., 2000. The role of Candida dubliniensis in oral candidiasis in human immunodeficiency virus infected individuals. Crit. Rev. Microbiol., 26, 59-68.

Sebti, A., Kiehn, T. E., Perlin, D., Chaturvedi, V., Wong, M., Doney, A., Park, S. and SepkoWITZ, K. A., 2001. Candida dubliniensis at a cancer center. Clin. Infect. Dis., 32, 1034-1038.

Staib, F. and Arasteh, K., 2001. Chlamydospore formation on Staib agar. Observations made before Candida dubliniensis was described. Mycoses., 44, 23-27.

Staib, P., Michel, S., Kohler, G. and Morschhauser, J., 2000. A molecular genetic system for the pathogenic yeast Candida dubliniensis. Gene, 242, 393-398.

Staib, P., Moran, G. P., Sullivan, D. J., Coleman, D. C. and Morschhäuser, J., 2001. Isogenic strain construction and gene targeting in Candida dubliniensis. J. Bacteriol., 183, 2859-2865.

STAIB, P. and MoRSCHHÄUSER, J., 1999. Chlamydospore formation on Staib agar as species-specific characteristic of Candida dubliniensis. Mycoses, 42, 521-524.

Sullivan, D., Bennet, D., Henman, M., Harwood, P., Flint, S., Mulcahy, D., Shanley, D. and Coleman, D., 1993. Oligonucleotide fingerprinting of isolates of Candida species other than Candida albicans and of atypical Candida species from human immunodeficiency virus positive and AIDS patients. J. Clin. Microbiol., 31, 2124-2133.

Sullivan, D. and Coleman, D., 1998. Candida dubliniensis, characteristics and identification. J. Clin. Microbiol., 36, 329-334.

Sullivan, D. and Coleman, D. C., 1997. Candida dubliniensis, an emerging opportunist pathogen. Curr. Top. Med. Mycol., 8, 15-25.

Sullivan, D., Haynes, K., Bille, J., Boerlin, P., Rodero, L., Lloyd, S., Henman, M. and ColeMAN, D., 1997b. Widespread geographic distribution of oral Candida dubliniensis strains in human immunodeficiency virus-infected individuals. J. Clin. Microbiol., 35, 960-964.

Sullivan, D. J., Henman, M. C., Moran, G. P., O’neill, L. C., Bennett, D. E. and Shanley, D. B., 1996. Molecular genetic approaches to identification, epidemiology and taxonomy of non-albicans Candida species. J. Med. Microbiol., 44, 399-408.

Sullivan, D. J., Moran, G., Donnelly, S., Gee, S., Pinjon, E., McCartan, B., Shanley, D. B. and Coleman, D. C., 1999. Candida dubliniensis, An update. Rev. Iberoam. Micol., 16, 72-76.

Sullivan, D. J., Westerneng, T. J., Haynes, K. A., Bennet, D. E. and Coleman, D. C., 1995. Candida dubliniensis sp. nov., phenotypic and molecular characterization of a novel species associated with oral candidosis in HIV-infected individuals. Microbiology, 141, 1507-1521.

TAmura, M., Watanabe, K., Imai, T., Mikami, Y. and NishimUra K., 2000. New PCR primer pairs specific for Candida dubliniensis and detection of the fungi from the Candida albicans clinical isolates in Japan. Clin Lab., 46, 33-40.

Timmins, E. M., Howell, S. A., Alsberg, B. K., Noble, W. C. and Goodacre, R., 1998. Rapid differentiation of closely related species and strains by pyrolysis-mass spectrometry and Fourier transform-infrared spectroscopy. J. Clin. Microbiol., 26, 367-374.

Tintelnot, K., HaAse, G., Seibold, M., Bergmann, F., Staemmler, M., Franz, T. and Naumann, D. 2000. Evaluation of phenotypic markers for selection and identification of Candida dubliniensis. J. Clin. Microbiol., 38, 1599-1608.

Torres-RodríGueZ, J. M., MÉndeZ, R., LóPEZ-Jodra, O., Morera, Y., EsPaSA, M., Jiménez, T. and LAGUNAS, C., 1999. In vitro susceptibilities of clinical yeast isolates to the new antifungal eberconazole compared with their susceptibilities to clotrimazole and ketoconazole. Antimicrob. Agents Chemother., 43, 1258-1259.

VelegraKi, A. and LogotheTI, M., 1998. Presumptive identification of an emerging yeast pathogen, Candida dubliniensis (sp. nov.) reduces 2,3,5-triphenyltetrazolium chloride. FEMS Immunol. Med. Microbiol., 20, 239-241.

Velegraki, A., Nicolatau, O., Theodoridou, M., Mostrou, G. and Legakis, N., 1999. Paediatric AIDS related linear gingival erythema, a form for erythematous candidiasis? J. Oral Pathol. Med., 28, $178-182$. 
Warren, N. G. and Hazen, K. C., 1999. Candida, Cryptococcus, and other yeasts of medical importance. In: Murray, P. R., Baron, E. J., Pfaller, M. A., Tenover, F. C., Yolken, R. H. (Eds.). Manual of Clinical Microbiology. $7^{\text {th }}$ ed. ASM Press., Washington., p, 1184-1199.

Williams, D. W., Coulter, W. A., Wilson, M. J., PotTs, A. J. and Lewis, M. A. O., 2001. Identification of Candida dubliniensis, based on ribosomal DNA sequence analysis. Br. J. Biomed. Sci., $\mathbf{5 8}, 11-16$.

Williams, D. W. and LEWIS, M. A. O., 2000. Isolation and identification of candida from the oral cavity. Oral Med., 6, 3-11.

Willis, A. M., Coulter, W. A., Sullivan, D. J., Coleman, D. C., Hayes J. R., Bell P. M. and LAMEY, P. J., 2000. Isolation of $C$. dubliniensis from insulin-using diabetes mellitus patients. J. Oral Pathol. Med., 29, 86-90.

Yokoyama, K., Biswas, S. K., MiYaJi, M. and Nishimura, K., 2000. Identification and phylogenetic relationship of the most common pathogenic Candida species inferred from mitochondrial cytochrome b gene sequences. J. Clin. Microbiol., 38, 4503-4510.

Mailing address: Prof. Dr. José GutiéRrez-FernándeZ, C/Camino Bajo de Huetor 84, $1^{\circ}$ A, E-18008 Granada, Spain

e-mail: josegf@ugr.es 